\title{
Green Synthesis Nanopartikel Perak (Agnps) Terkonjugasi Etil Parametoksi Sinamat (Epms) sebagai Bahan Tabir Surya
}

\author{
(Green Synthesis of Nanopartikel Perak (Agnps) Terkonjugasi Etil Parametoksi Sinamat \\ (Epms) Sebagai Bahan Tabir Surya)
}

\section{Agustina, Munawarah, Stefanus Agustinus Lumi, Syamsu Nur}

Akademi Farmasi Kebangsaan Makassar, Jalan Perintis Kemerdekaan Km. 13,7 Daya, Makassar 90242

\begin{tabular}{l} 
Article Info: \\
Received: 9 Juli 2018 \\
in revised form: 15 Agustus \\
Accepted: 15 September 2018 \\
Available Online:30 September 2018 \\
\hline \\
Keywords: \\
green synthesis \\
nanopartikel perak \\
rimpang kencur \\
EPMS \\
tabir surya
\end{tabular}

Corresponding Author: Syamsu Nur

Akademi Farmasi Kebangsaan Makassar 90242

Syamsunur19@gmail.com

\begin{abstract}
Green Synthesis is a method to make silver nanoparticles (AgNPs) by utilizing natural materials as bioreductors. One of the natural materials that can reduce metal ions is Kaempferia galanga rhizome because it has a chemical component that can penetrate the metal. The compounds are ethyl paramethoxycinnamate (EPMC) which is used as sunscreen. This study aims to produce AgNPs conjugated with EPMC that can be used as raw material sunscreen. This study was conducted by extracting EPMS from the Kaempferia galanga rhizome and synthesizing the AgNPs conjugated with EPMC. The synthesis results were characterized by UV-Vis Spectrophotometry, FTIR, SEM, PSA and sunscreen activity. Extracted result was obtained crystalline is ethyl paramethoxycinnamate compound with yield 2,3\%. The characterization of EPMC with UV-Vis spectrophotometer was obtained maximum wavelength of $308 \mathrm{~nm}$ and FTIR analysis result at wave number 1701,27 cm-1 indicated the presence of carbonyl group $(C=O)$ and 1165,97 cm-1 presence of $C-O$ and showed specific characteristic from EPMS. Characterization of AgNPs using UvVis spectrophotometer was obtained maximum wavelength of $469 \mathrm{~nm}$. Characterization of AgNPs using SEM are spherical and monodispers forms. Then, particle size using PSA obtained an average diameter of 182 $n m$. AgNPs conjugated with EPMS has a sunscreen activity with sunblock category and successfully provide protection against UV exposure at low concentration (200 ppm) categorized as ultra protection with SPF value 36,4 .
\end{abstract}

How to cite (APA 6th Style):

Agustina, et al. (2018). Green Synthesis Nanopartikel Perak (Agnps) Terkonjugasi Etil Parametoksi Sinamat (Epms) sebagai Bahan Tabir Surya. Jurnal Farmasi Galenika : Galenika Journal of Pharmacy, 4(2), 98-105. doi:10.22487/j24428744.2018.v4.i2.10440 


\begin{abstract}
ABSTRAK
Green Synthesis merupakan metode pembuatan nanopartikel perak (AgNPs) dengan memanfaatkan bahan alam sebagai bioreduktor. Salah satu bahan alam yang mampu mereduksi ion logam karena memiliki komponen kimia yang dapat berpenetrasi pada logam adalah rimpang kencur. Senyawa yang terdapat didalamnya adalah etil parametoksi sinamat (EPMS) yang dimanfaatkan sebagai tabir surya. Penelitian ini bertujuan untuk menghasilkan AgNPs yang terkonjugasi dengan EPMS yang dapat digunakan sebagai bahan baku tabir surya. Penelitian ini dilakukan dengan mengekstraksi EPMS dari rimpang kencur dan mensintesis AgNPs terkonjugasi dengan EPMS. Hasil sintesis dikarakterisasi dengan Spektrofotometri UVVis, FTIR, SEM, PSA serta dilakukan uji aktivitas tabir surya. Hasil ektraksi didapatkan senyawa etil parametoksi sinamat (EPMS) berbentuk kristal dengan persen rendamen 2,3\%. Karakterisasi EPMS dengan spektrofotometer Uv-Vis diperoleh panjang gelombang maksimum $308 \mathrm{~nm}$ dan hasil analisis FTIR pada bilangan gelombang 1701,27 $\mathrm{cm}^{-1}$ mengindikasikan adanya gugus karbonil $(\mathrm{C}=\mathrm{O})$ dan 1165,97 $\mathrm{cm}^{-1}$ adanya gugus C-O yang spesifik menunjukkan ciri khas dari EPMS. Karakterisasi AgNPs menggunakan spektrofotometer Uv-Vis diperoleh panjang gelombang maksimum $469 \mathrm{~nm}$. Karakterisasi menggunakan SEM diperoleh AgNPs yang berbentuk bulat dan mono-dispers dan ukuran partikel menggunakan PSA diperoleh diameter rata-rata $182 \mathrm{~nm}$. EPMS AgNPs terkonjugas EPMS memiliki aktivitas sebagai tabir surya dengan kategori sunblock dan berhasil memberikan perlindungan terhadap paparan sinar UV pada konsentrasi rendah (200 ppm) yang dikategorikan sebagai proteksi ultra dengan nilai SPF sebesar 36.4.
\end{abstract}

Kata kunci : green synthesis, nanopartikel perak, rimpang kencur, EPMS, tabir surya

\section{PENDAHULUAN}

Nanopartikel merupakan suatu partikel dengan ukuran nanometer, yaitu sekitar 1-100 nm (Hosokawa, Naito, Nogi, \& Yokoyama, 2007). Salah satu material logam yang disintesis sebagai nanopartikel adalah perak. Perak yang tersintesis menjadi nanopartikel memiliki banyak kegunaan diberbagai bidang seperti bidang teknologi, kesehatan dan kosmetik (Gajbhiye \& Sakharawade, 2016).

Nanopartikel perak (AgNPs) dapat dihasilkan dari berbagai variasi metode meliputi fotokimia, sonokimia, radiasi ultrasonik, sintesis solvotermal, poliol dan reduksi kimia ion perak dengan atau tanpa agen stabilisator (Guzmán, Dille, \& Godet, 2008). Metode tersebut telah digunakan dan mampu menghasilkan AgNPs dengan karakteristik yang baik. Namun dibutuhkan banyak biaya, energi dan bahkan material tambahan sehingga metode tersebut kurang efisien jika ingin digunakan dalam skala yang besar (Khoury, Abiad, Kassaify, \& Patra, 2015).
Pengembangan metode yang lain dalam mensintesis AgNPs dapat dilakukan dengan menggunakan teknik green synthesis. Green synthesis merupakan metode pembuatan AgNPs dengan memanfaatkan bahan alam sebagai bioreduktor (Makarov et al., 2014). Keuntungan dari green synthesis tersebut adalah ramah lingkungan, metode yang sederhana dan meminimalisir terjadinya toksisitas dari material yang terbentuk (Khoury, Abiad, Kassaify, \& Patra, 2015).. Bahan alam yang berasal dari tanaman diketahui mampu mereduksi ion logam seperti ion perak (Ag+) menjadi Ag dikarenakan tanaman memiliki komponen kimia yang dapat berpenetrasi pada logam (Makarov et al., 2014). Salah satu senyawa dari tanaman yang dapat digunakan sebagai bioreduktor adalah rimpang kencur (Kaemperia galanga L.). Rimpang kencur merupakan tanaman dari famili zingiberaceae yang banyak digunakan dalam pengobatan tradisional. Kandungan senyawa kimia dari rimpang kencur antara lain minyak atsiri berupa Etil parametoksi sinamat, metal sinamat, karvon, 
eucalyptol, pentadekana, borneol dan kamfen (Tewtrakul, Yuenyongsawad, \& Kummee, 2005). Ester etil sinamat seperti etil parametoksi sinamat (EPMS) merupakan salah satu senyawa kimia yang paling banyak terdapat pada rimpang kencur dan menjadi bagian yang sangat penting didalam industri kosmetik karena memiliki manfaat sebagai bahan pemutih dan antiaging atau penuaan pada jaringan kulit (Rosita, Rostiana, \& Haryudin, 2006). Selain itu, etil parametoksi sinamat (EPMS) juga dapat digunakan sebagai pelindung kulit dari radiasi sinar matahari. Hal ini dikarenakan turunan sinamat memiliki rantai panjang dan sistem ikatan rangkap yang terkonjugasi memungkinkan terjadinya proses resonansi ketika terkena radiasi sinar UV (Taufikkurohmah, 2005).

Berdasarkan hal tersebut, maka EPMS dari rimpang kencur dapat digunakan sebagai kandidat senyawa bahan alam yang akan dikonjugasikan untuk menghasilkan AgNPs. AgNPs yang terkonjugasi dengan EPMS dari rimpang kencur diharapkan dapat diaplikasikan sebagai bahan tabir surya yang lebih efektif dan aman dalam melindungi kulit dari paparan sinar UV yang berlebihan. Oleh karena itu, perlu dilakukan penelitian agar dapat dihasilkan kandidat bahan aktif kosmetik tabir surya.

Penelitian bertujuan menghasilkan AgNPs yang terkonjugasi dengan etil parametoksi sinamat (EPMS) dari rimpang kencur dan menghasilkan AgNPs yang dapat digunakan sebagai kosmetik tabir surya.

\section{METODE PENELITIAN Alat Dan Bahan}

Alat yang digunakan antara lain alat-alat gelas, bejana maserasi, hot plate (Nesco Lab MS-H280Pro), Particle Size Analyser (PSA Horiba SZ-100), Scanning Electron Microscope (SEM VEGA 3Tescan), Sentrifus (DSC-200T), Spektrofotometer FT-IR, Spektrofotometer UV-Vis (Shimadzu UV 1800), grinder dan oven (Memmert), Rotary Evaporator (IKA-RV 8V), Neraca Analitik (Metler Toledo AL-204).

Bahan yang digunakan yaitu air suling (waterone), etanol 70\% (onemed), etanol 96\% (onemed), etanol
p.(Merck-Germany), gliserol, perak nitrat $\left(\mathrm{AgNO}_{3}\right)$ (Merck-Germany), rimpang kencur dan polyvinylpyrolidone (PVP) (Merck-Germany).

\section{Determinasi Sampel}

Sampel segar rimpang kencur diambil dari Perkebunan di Rappang, Kabupaten Sidrap, Provinsi Sulawesi Selatan dan dideterminasi sampel rimpang kencur di Laboratorium Biologi, Fakultas MIPA Universitas Negeri Makassar.

\section{Pembuatan Simplisia}

Lima kilogram rimpang kencur diambil kemudian dicuci bersih dengan air mengalir, dirajang hingga berbentuk potongan kecil lalu dikeringkan hingga diperoleh simplisia kering kemudian di serbuk menggunakan grinder.

\section{Ekstraksi etil parametoksi sinamat (EPMS) dari rimpang kencur}

Metode ekstraksi etil parametoksi sinamat (EPMS) diadopsi dari penelitian Taufikkuromah (2005) yang berhasil mengisolasi EPMS dengan sedikit dimodifikasi yang dilakukan dengan cara serbuk kering rimpang kencur ditimbang sebanyak $1 \mathrm{~kg}$ dan dimaserasi dengan etanol 96\% selama 1 x 24 jam. Maserat yang diperoleh dari hasil ekstraksi dipekatkan sampai diperoleh kira-kira $100 \mathrm{~mL}$ maserat pekat. Maserat di dinginkan dalam lemari pendingin sampai terbentuk kristal putih. Kristal yang terbentuk disaring dengan corong buchner. Kristal dilarutkan dalam etanol 70\% panas dan dipanaskan sampai cepat larut. Lalu ditambahkan air secara perlahan-lahan sambil diaduk. Penambahan air dihentikan tepat setelah larutan menjadi keruh. Larutan tersebut kemudian disaring panas dan filtrat didinginkan hingga terbentuk kristal. Kristal disaring dengan corong buchner, lalu dikeringkan dalam oven. Kemudian dihitung \% rendemen kristal EPMS.

\section{Sintesis Ag NP terkonjugasi ekstrak EPMS}

Sintesis nanopartikel perak dilakukan dengan mengacu pada Khoury, Abiad, Kassaify, \& Patra, (2015), yang dilakukan dengan cara melarutkan perak nitrat dengan air suling (1 mM) dan dicampur dengan 
1,5 g gliserol. Pengadukan dijaga pada suhu $90^{\circ} \mathrm{C}$ dan EPMS (50 mg dalam10 mL etanol) ditambahkan ke dalam larutan, kemudian distirer dan diamati reaksinya berdasarkan perubahan warna selama 70 menit dengan interval setiap 10 menit dan dikarakterisasi meggunakan Spektrofotmeter UVVis. Bila terjadi perubahan warna dari kuning menjadi jingga, maka ditambahkan 3 g PVP dan larutan distirer. Larutan yang diperoleh disentrifus pada 10.000 rpm selama 15 menit. Nanopartikel yang diperoleh dicuci dengan air suling dan selanjutnya di freze drying untuk memperoleh serbuk nanopartikel perak.

\section{Karakterisasi Ag NP}

Nanopartikel perak dikarakterisasi dengan menggunakan Spektrofotometer UV-Vis pada rentang panjang gelombang 400-500 nm, analisis FTIR untuk menentukan gugus fungsi senyawa, dan analisis Scanning Electron Microscope (SEM) untuk penentuan morfologi AgNP. Sedangkan untuk penentuan ukuran dari nanopartikel dilakukan dengan menggunakan Particle Size Analyser (PSA).

\section{Penentuan Nilai Transmisi Eritema dan Pigmentasi}

Nanopartikel perak dibuat seri kadar dari 1-1000 ppm dan diukur absorbansinya untuk menentukn nilai transmisi eritema pada panjang gelombang 292,5$337,5 \mathrm{~nm}$ dan pigmentasi pada panjang gelombang $292,5-372,5 \mathrm{~nm}$.

Nilai transmisi eritema dan pigmentasi diperoleh dari hasil perkalian masing-masing nilai transmisi $(\mathrm{T})$ dengan faktor keefektifan eritema (Fe) dan pigmentasi ( $\mathrm{Fp}$ ) pada panjang gelombang penyebab eritema dan pigmentasi. Persentase eritema dapat di hitung dengan rumus :

\% Transmisi Eritema :

$$
\mathrm{Te}=\frac{\sum \mathrm{Ee}}{\sum \mathrm{Fe}}=\frac{\sum(\mathrm{T} \times \mathrm{Fe})}{\sum \mathrm{Fe}}
$$

Sedangkan Persentase pigmentasi dapat di hitung dengan rumus :

\% Transmisi Pigmentasi :

$$
\mathrm{Tp}=\frac{\sum \mathrm{Ep}}{\sum \mathrm{Fp}}=\frac{\sum(\mathrm{T} \times \mathrm{Fp})}{\sum \mathrm{Fp}}
$$

Dimana, Ee/Ep = Energi eritema/Energi Pigmentasi, $\mathrm{T}=$ Transmisi, $\quad$ Fe/Fp $=$ Faktor keefektifan eritema/Pigmentasi

\section{Penentuan Nilai SPF (Sun Protective Factor)}

Masing-masing ekstrak kencur dibuat seri kadar dari konsentrasi 1 -1000 ppm. Spektrofotometer UV-Vis dikalibrasi terlebih dahulu dengan menggunakan etanol $70 \%$ dan sebanyak $1 \mathrm{~mL}$ dimasukkan ke dalam kuvet. Dibuat kurva serapan uji dalam kuvet dengan panjang gelombang antara 290-320 nm, etanol p.a digunakan sebagai blanko. Kemudian ditetapkan serapan rata- ratanya dengan interval 5 nm. Hasil absorbansi masing-masing konsentrasi dicatat dan kemudian nilai SPFnya dihitung. Nilai SPF dianalisis menggunakan metode yang dikemukakan oleh Mansur, Breder, Mansur, \& Azulay (1986) sebagai berikut:

$$
\begin{aligned}
& \text { SPF Spektrofotometer }= \\
& \mathrm{CF} \times \sum_{290}^{320} \mathrm{EE}(\lambda) \times \mathrm{I}(\lambda) \times \operatorname{Abs}(\lambda)
\end{aligned}
$$

Dimana, $\mathrm{CF}=$ Faktor Korelasi, $\mathrm{I}=$ Spektrum Simulasi Sinar Surya, EE = Efisiensi Eritema dan Abs $=$ Absorbansi

\section{HASIL DAN PEMBAHASAN}

\section{Ekstraksi dan Karakterisasi EPMS}

Kristal EPMS diperoleh dari rimpang kencur (Kaempferia galangal) yang melibatkan proses ekstraksi dengan metode maserasi menaggunakan etanol 96\% dan kristalisasi yang melibatkan pendinginan. Maserat etanol 96\% dipekatkan hingga diperoleh maserat sekitar $100 \mathrm{~mL}$ dan disimpan dalam lemari pending untuk memperoleh Kristal. Kristal yang diperoleh direkristalisasi untuk mendapatkan Kristal EPMS. Dari hasil penelitian diperoleh kristal EPMS yang berwarna putih kekuningan dengan rendemen sebesar 2,22\%.

Kristal EPMS yang diperoleh selanjutnya dikarakterisasi menggunakan Spektrofotmeter UVVis dan FT/IR yang bertujuan untuk mengetahui 
keberadaan dari senyawa EPMS yang diisolasi dari rimpang kencur. Dari hasil pengukuran menggunakan Spektrofotometer UV-Vis diperoleh spektrum UV.

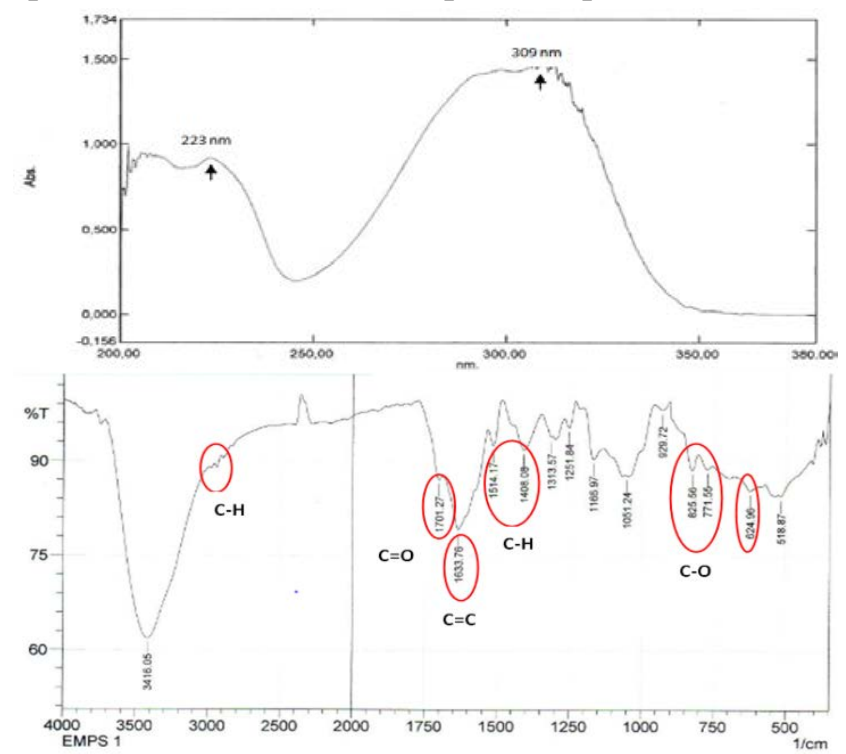

Gambar 1. Pola Spektrum (a) Uv-Vis dan (b) FT-IR Spektrofotometer dari EPMS

Pada Gambar 1a dihasilkan pola spectrum Uv-Vis dengan 2 puncak senyawa yaitu pada panjang gelombang $223 \mathrm{~nm}$ (pola spectrum aromatic terkonjugasi) dan $309 \mathrm{~nm}$ (pola spectrum sinamoil yang terdapat pada EPMS). Hal ini telah diperoleh data yang sama dari penelitian Taufikkurohmah (2005), yang berhasil mengisolasi EPMS dari kencur dengan pola spectrum UV-Vis diperoleh pada panjang gelombang $308 \mathrm{~nm}$.

Karaketerisasi selanjutnya dilakukan dengan menggunakan analisis secara FT-IR (Gambar 1b). Analisis FT-IR bertujuan untuk mengidentifikasi gugus-gugus yang terikat dengan senyawa kompleks hasil sintesis. Analisis ini dilakukan pada frekuensi 500-4000 $\mathrm{cm}^{-1}$. Berikut adalah hasil analisis menggunakan FTIR.

Tabel 1. Data hasil analisis spectrum IR senyawa EPMS

\begin{tabular}{|c|c|c|c|}
\hline No & $\begin{array}{l}\text { Frekuensi } \\
\left(\mathrm{cm}^{-1}\right)\end{array}$ & $\begin{array}{l}\text { Rentang } \\
\left(\mathrm{cm}^{-1}\right)^{*}\end{array}$ & Prediksi \\
\hline 1 & 2933,83 & $\begin{array}{l}\text { Dekat } 3000 \\
(<)\end{array}$ & C-H (strech) \\
\hline 2 & 1701,27 & $1820-1660$ & $\mathrm{C}=\mathrm{O}$ (strech) \\
\hline 3 & $\begin{array}{l}1633,76 \text { dan } \\
1514,17\end{array}$ & $1660-1450$ & $\mathrm{C}=\mathrm{C}$ (aromatik) \\
\hline
\end{tabular}

\begin{tabular}{|c|c|c|c|}
\hline 4 & 1408,09 & $1475-1365$ & C-H (sp2 dan sp3) \\
\hline & 1165,97 dan & $1300-1000$ & $\mathrm{C}-\mathrm{O}($ stretch $)$ \\
\hline & $\begin{array}{l}1051,24 \\
825,50\end{array}$ & $1000-800$ & $\begin{array}{l}\text { Aromatik } \\
\text { disubstitusi** }\end{array}$ \\
\hline
\end{tabular}

Pavia et al (2001) Qudsi H (2014).

Hasil penafsiran spektrum IR yang ditunjukkan pada tabel 1 dan Gambar 1b menyatakan bahwa pada bilangan gelombang 2933,83 $\mathrm{cm}^{-1}$ merupakan bilangan gelombang yang spesifik vibrasi ulur ikatan anatara $\mathrm{C}-\mathrm{H}$ pada gugus aromatik. kemudian pada daerah bilangan gelombang 1701,27 $\mathrm{cm}^{-1}$ mengindikasikan adanya gugus karbonil $(\mathrm{C}=\mathrm{O})$ dan spesifik menunjukkan ciri khas dari EPMS. Ciri khas selanjutnya ditunjukkan pada daerah bilangan gelombang 1165,97 dan 1051,24 $\mathrm{cm}^{-1}$ mengindikasikan adanya gugus ester/eter $(\mathrm{C}-\mathrm{O})$ dan disubstitusi pada posisi para ditunjukkan pada daerah bilangan gelombang 825,5 $\mathrm{cm}^{1}$. Gambar 2 merupakan struktur dari Etil p-metoksi sinamat (EPMS).<smiles>CCOC(=O)/C=C/c1ccc(OC)cc1</smiles>

Gambar 2. Struktur Molekul Etyl Parametoksi Sinamat (EPMS).

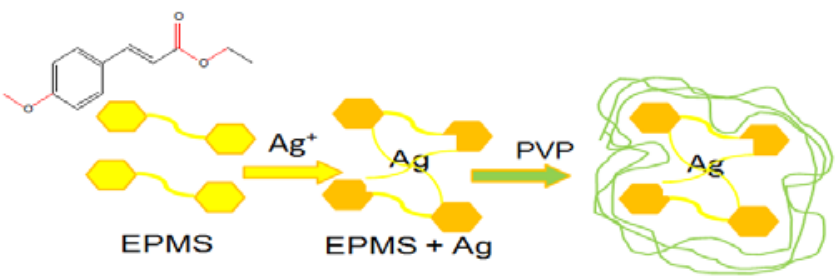

Gambar 3. Ilustrasi mekanisme pembentukan AgNPs.

\section{Pembuatan dan Karakterisasi AgNPs Terkonjugasi EPMS}

AgNPs merupakan nanopartikel yang dapat disintesis dengan menggunakan suatu agen yang berasal dari bahan alam. Prinsip dari metode ini adalah terjadinya reduksi ion $\mathrm{Ag}^{+}$menjadi $\mathrm{Ag}^{0}$ sehingga dengan adanya reduksi tersebut akan memudahkan untuk terjadinya pembentukan nanopartikel silver. Proses 
pembentukan AgNPs distabilkan dengan menggunakan gliserol dan PVP sehingga dapat mencegah terjadinya agregasi dari AgNPs yang terbentuk. Gambar 3 merupakan ilustrasi dari proses pembentukan AgNPs yang terkonjugasi dengan EPMS.

Proses pembentukan AgNPs dimonitoring selama 70 menit dan dilakukan setiap interval 10 menit kemudian ditentukan panjang gelombang maksimum AgNPs yang terbentuk. Dari hasil monitoring yang dilakukan diperoleh panjang gelombang maksimum 469 nm (Gambar 4) yang mana pada panjang gelombang tersebut menunjukkan adanya AgNPs yang terbentuk. Hal ini dapat dilihat jika terdapat puncak yang tajam yang terjadi pada panjang gelombang 400-500 nm (Dyal et al., 2006). Berikut adalah pola spectrum Uv-Vis dari AgNPs.

Data Set: File_090505_PGM nano perak - RawData

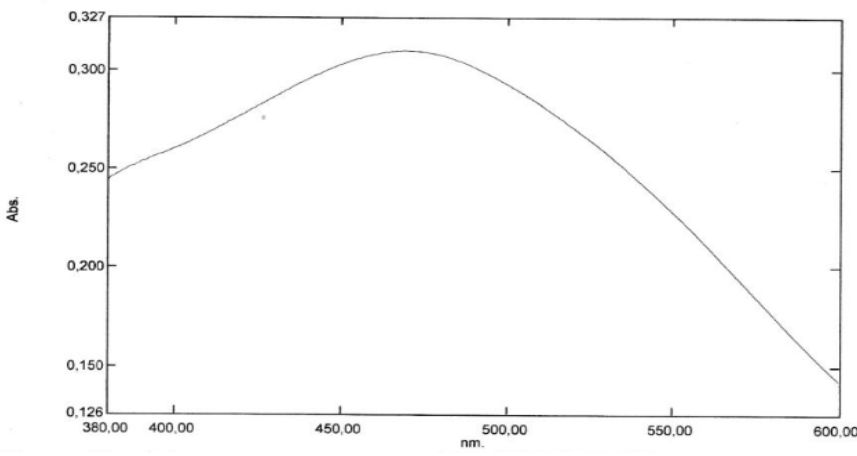

Gambar 4. Pola spectrum UV-Vis AgNPs.

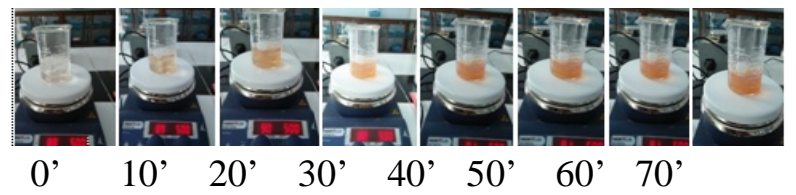

Gambar 5. Hasil monitoring pembentukan AgNPs.

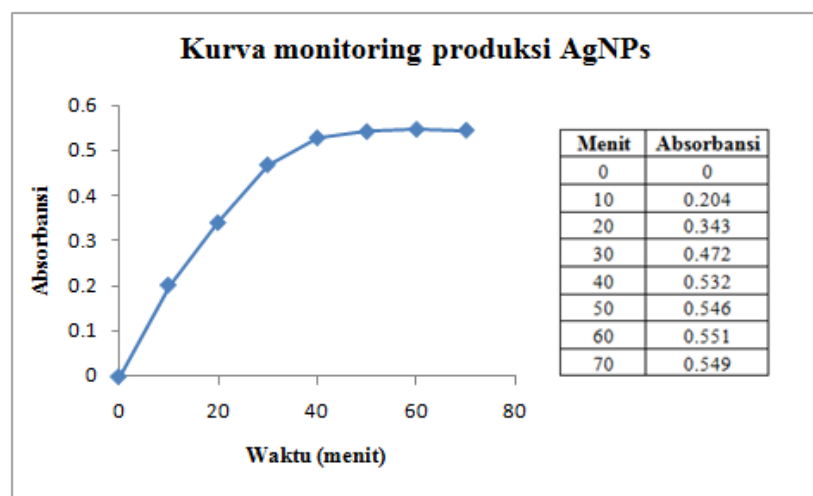

Gambar 6. Kurva pembentukan AgNPs pada panjang gelombang $469 \mathrm{~nm}$

Hasil pada Gambar 5 menunjukkan bahwa pembentukan AgNPs yang terjadi ditandai dengan perubahan warna bening menjadi warna jingga. Hal ini merupakan identifikasi awal yang menunjukkan pembentukan AgNPs. Ketika perubahan warna mulai berubah dari jingga menjadi kemerahan maka ditambahkan PVP sebagai penstabil. Oleh karena itu, pada menit ke-40 sebanyak 0,5 gram PVP ditambahkan sehingga perubahan warna dapat diatasi serta peningkatan absorbansi juga mulai berkurang. Hal ini terlihat pada grafik Gambar 6 yang menunjukkan bahwa pada menit ke-40 sampai ke-70 nilai absorbansi sampel tidak berbeda signifikan.

Untuk penentuan karakteristik morfologi dan ukuran partikel dari AgNPs dilakukan dengan menggunakan SEM (Scanning Electron Microscope) dan PSA (Particle Size Analyzer). Pada Gambar 6a merupakan hasil pengukuran menggunakan SEM yang menunjukkan bahwa partikel AgNPs memberikan bentuk bulat mono-disper. Adanya penambahan gliserol dalam proses sintesis AgNPs membantu dalam pembentukan AgNPs yang mono-dispers. Namun, pada perbesaran tertentu AgNPs yang dihasilkan masih membentuk agregat. Hal ini juga diperoleh hasil pengukuran PSA berdasarkan pada Gambar 6b yang menunjukkan diameter ukuran partikel AgNPs diperoleh nilai rata-rata $182 \mathrm{~nm}$. 


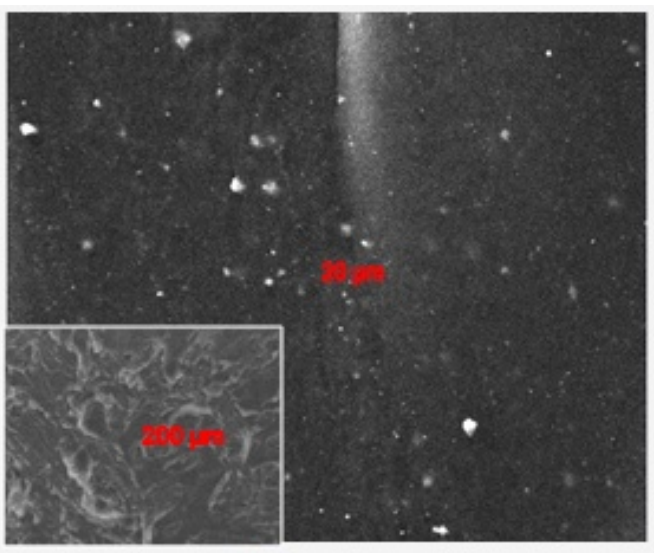

a

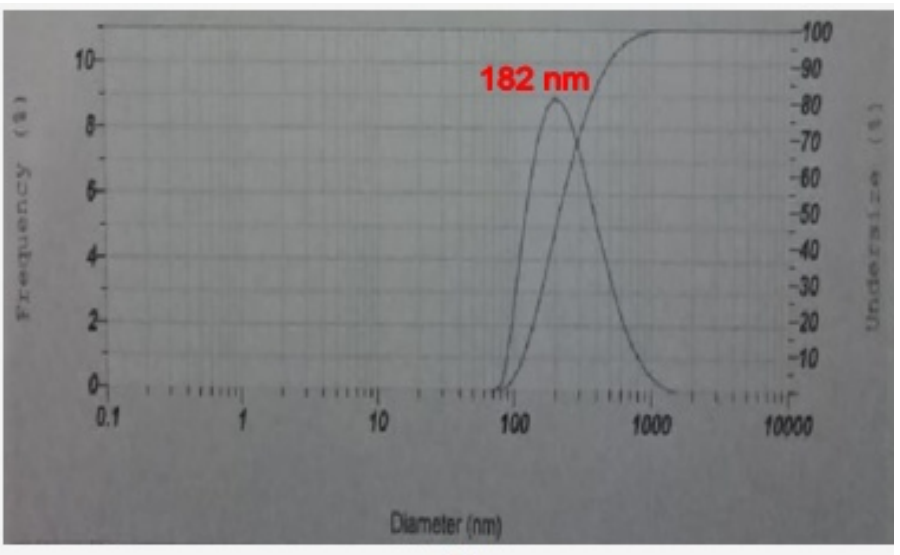

$\mathrm{b}$

Gambar 6. Hasil pengukuran (a) SEM pada perbesaran $10 \mu \mathrm{m}$ dan $200 \mu \mathrm{m}$, (b) PSA

Tabel 2. Hasil perhitungan \%transmisi eritema, persentase pigmentasi dan SPF

\begin{tabular}{cccccc}
\hline Konsentrasi & $\begin{array}{c}\text { \% Transmisi } \\
\text { Eritema }\end{array}$ & $\begin{array}{c}\text { \% Transmisi } \\
\text { Pigmentasi }\end{array}$ & Kategori & SPF & Kategori \\
\hline $\begin{array}{c}\text { AgNPs } \\
\text { Konjugasi EPMS } \\
200 \mathrm{ppm}\end{array}$ & 0.155 & 31.6 & Sunblock & 36.4 & $\begin{array}{c}\text { Proteksi } \\
\text { Ultra }\end{array}$ \\
\hline EPMS 1000 ppm & 0.078 & 7.51 & Sunblock & 38.46 & $\begin{array}{c}\text { Proteksi } \\
\text { Ultra }\end{array}$ \\
\hline
\end{tabular}

Diameter tersebut cukup besar meskipun dalam pembuatan AgNPs terdapat penambahan PVP sebagai stabilisator untuk mencegah agregasi. Hal ini dapat terjadi karena adanya pengaruh dari EPMS yang tetap terkonjugasi dengan AgNPs sehingga mempengaruhi diameter nanopartikel yang terbentuk masih besar.

\section{Pengujian Aktivitas Tabir Surya dari AgNPs}

Pengujian aktivitas tabir surya menggunakan 3 metode yaitu perhitungan persentase transmisi eritema, persentase transmisi pigmentasi dan nilai Sun Protection Faktor (SPF) menggunakan spektrofotometer UV-Vis dengan mengamati serapan larutan sampel AgNPs terkonjugasi EPMS yang diuji yaitu sebesar 200 ppm pada panjang gelombang 292$372 \mathrm{~nm}$ sedangkan untuk sampel EPMS tanpa AgNPs dengan konsentrasi 1000 ppm.

Pada pengujian tabir surya dikategorikan sebagai sunblock jika nilai transmisi eritema $<1 \%$ dan transmisi pigmentasi 3-40\%. Untuk kategori suntan jika nilai transmisi eritema 6-18\% dan transmisi pigmentasi 45-86\% (Cumpelik, 1972)

Dari data Tabel 2 menunjukkan bahwa, AgNPs terkonjugasi EPMS dengan konsentrasi 200 ppm dapat dikategorikan sebagai sunblock dengan nilai SPF 36,4 sedangkan EPMS tanpa konjugasi AgNPs pada konsentrasi 1000 ppm dengan nilai SPF 38,4. Hal ini dapat disimpulkan bahwa sampel AgNPs yang terkonjugasi EPMS dengan konsentrasi kecil memiliki daya perlindungan ultra jika dibandingkan dengan tanpa konjugasi AgNPs.

\section{KESIMPULAN}

Berdasarkan hasil penelitian dapat disimpulkan bahwa AgNPs dapat dikonjugasikan dengan EPMS dari rimpang kencur yang memiliki karakteristik berbentuk bulat monodispers meskipun agregasi yang terjadi tidak dapat dihindari selama proses sintesis. AgNPs terkonjugasi EPMS dapat diaplikasikan sebagai bahan aktif tabir surya dengan kategori 
sunblock dan memberikan perlindungan terhadap paparan sinar UV pada konsentrasi rendah (200 ppm) yang dikategorikan sebagai proteksi ultra dengan nilai SPF sebesar 36.4.

\section{UCAPAN TERIMAKASIH}

Peneliti mengucapkan terimakasih kepada Dirjen Belmawa KemenRistekDikti berupa pendanaan PKM-P Tahun 2018.

\section{DAFTAR PUSTAKA}

Cumpelik, B.M., (1972), Analytical Procedures and Evaluation of Sunscreen, Journal of The Society of Cosmetic Chemists, 23(6), 333345.

Dyal, C., Nguyen, N., Hadden, J., Gou, L., Li, T., Murphy, C. J., ... Nivens, D. (2006). Green Synthesis of Gold and Silver Nanoparticles from Plant Extracts. Armstrong Atlantic State University.

Gajbhiye, S., \& Sakharwade, S. (2016). Silver Nanoparticles in Cosmetics. Journal of Cosmetics, Dermatological Sciences and Applications, (6), 48-53.

Guzmán, M. G., Dille, J., \& Godet, S. (2008). Synthesis of silver nanoparticles by chemical reduction method and their antibacterial activity. International Journal of Materials and Metallurgical Engineering, 2(7), 91-98.

Hosokawa, M., Naito, M., Nogi, K., \& Yokoyama, T. (2007). Nanoparticle technology handbook $1^{\text {st }}$ edition. Amsterdam: Elsevier.

Khoury, E. El, Abiad, M., Kassaify, Z. G., \& Patra, D. (2015). Green synthesis of curcumin conjugated nanosilver for the applications in nucleic acid sensing and anti-bacterial activity. Colloids and Surfaces B: Biointerfaces, 127, 274-280.

Makarov, V. V, Love, A. J., Sinitsyna, O. V, Makarova, S. S., Yaminsky, I. V, Taliansky, M. E., \& Kalinina, N. O. (2014). " Green ”
Nanotechnologies: Synthesis of Metal Nanoparticles Using Plants. Russian Academy of Sciences, 6(20), 35-44.

Mansur JS, Breder MN, Mansur MC, Azulay RD (1986) Determination of Sun Protection Factor by Spectrophotometry. An Bras Dermatol, 6. 121-124.

Rosita, S.M.D., Rostiana, O., Haryudin, W. (2006). Respon kencur (Kaempferia galanga L.) terhadap pemupukan. Prosiding Seminar Nasional dan Pameran Tumbuhan Obat Indonesia XXVIII.

Taufikkurohmah, T. (2005). Synthesis of p-methoxycynnamil- p-metoxycinamate from ethyl pmethoxycinamat was isolated from dried rhizome kaempferia galanga $l$ as sunscreen compound. Indo. J. Chem, 5(3), 193-197.

Tewtrakul, S., Yuenyongsawad, S., \& Kummee, S. (2005). Chemical components and biological activities of volatile oil of Kaempferia galanga Linn. J. Sci. Technol, 27, 503-507. 